\title{
Spontaneous Flow of Colonialism: A Postcolonial Reading of Joseph Conrad's Heart of Darkness
}

\author{
Yuandan Huang \\ College of Foreign Languages and Cultures, Sichuan University, Chengdu 610000, China \\ selene304@163.com
}

\begin{abstract}
To a large extent, practice in post-colonialist criticism begins with a re-reading of Joseph Conrad's famous work Heart of Darkness. Those interpretations, more often than not, tend to focus on Conrad's questioning and exposing of Europe's colonial expansion, while overlooking the co-existence of its colonial discourse and postcolonial criticism. Conventional research subjects like plot or personal relationship aside, this paper aims to pursue, by means of post-colonial criticism, the spontaneous flow of Conrad's colonial tendency through a detailed analysis of implicit discourses like the one-sided allocation of power discourse, the presumption of a contrived dualistic distinction between "us” and “other” and, above all, his tacit approval of Europe’s culture hegemony.
\end{abstract}

Keywords: Postcolonialism, power/discourse, us/other, culture hegemony.

\section{Introduction to Postcolonialism and Conrad}

\subsection{Brief Introduction to Postcolonial Criticism}

With the publication of Edward Said's Orientalism in 1978, there emerged in the academic arena a new mode of cultural analysis -- postcolonialism, an analytic methodology aimed at analyzing conflicts between different cultures, usually that between a colonial power and its corresponding colonized one. For all the controversies about its research scope in terms of time and space, there do exist a consensus over some of its basic premises: its reliance on Foucault's power/discourse theory; the presence of a contrived dualistic distinction between "us" and "other"; and the utilization of Gramsci's cultural hegemony theory. These three points, once acknowledged, serves the major guild-line for the exploration of Conrad's tacit expression of colonial consciousness in his outspoken postcolonial work.

\subsection{A Brief Introduction to Conrad}

Joseph Conrad(1857-1924), originally a citizen of Poland, a country in the coffin then (Harpman 1), joined the British citizenship in 1886. A naturalized British as he was, the identity as a Polish citizen remained with him, just as he himself would always preferred to be considered a Pole. The dual influence of his childhood experience which was deeply haunted by the colonial oppression in his greatly humiliated motherland and his citizenship of the most developed power in the world, inevitably rendered him a mixture of "us" and "other", or to put it another way, ineluctably contributed to his sway of identification with those being oppressed and those inflicting oppression. This is exactly the basis for a detailed discussion of Cnorad's colonial tendency which would otherwise be overlooked by many.

\section{Analysis of Conrad's Colonial Tendency through Detailed Investigation into Three Different Kinds of Implicit Discourses}

\subsection{The One-Sided Allocation of Power Discourse}

In his inaugural lecture The Order of Discourse at the Collège de France, Michel Foucault stated that "Discourse is the power which is to be seized," (53) and that it has a subjective power which went beyond the play of desire and bureaucratic institutions, a truth manifested in the fact that "in every society the production of discourse is at once controlled, selected, organized and redistributed by a certain number of procedures whose role is to ward off its powers and dangers, to gain mastery over its chance events, to evade its ponderous, formidable materiality."(52) So discourse is not simply that 
which expresses struggles and macanisms of dominance. It is the thing for which and by which there is struggle. Through the mastery of discourse, man gets power.

This theory, when applied to the analysis of literary works, mainly expressed in the form of the author's allocation of power discourse, or to put it more specifically, the design of narrative perspective, can help a lot in perceiving the author's stance, namely for whom, or which group he is speaking, be it implicitly or explicitly.

Anyone who has ever read Conrad's novel Heart of Darkness would have noticed that the novel was comprised of Marlow's narration, kind of in the form of a monologue. We see everything through Marlow's eyes. It was through him that we get an access to that world, as if personally on the scene. Yet anyone with a more acute insight would notice a problem in that ready presented world -- it was incomplete! Beyond the world of white, there was a vast blind area, a world of the black, underrepresented and marginalized. When we moved around with Marlow, we saw no significant indigenous character, nor did we hear any clear understandable discourse from them. Even if there was, it was only in the background, and was by no means rendered pleasing to the ears, like that what Marlow described as "the tongue of wild mob" (Conrad 96). This way, the black were very much destroyed, silenced and erased.

So in bestowing Marlow, a white European, who himself also joined the so-called expansion enterprise, thus kind of a spokesman for the white, this paramount discourse power, Conrad made the whole narrative pattern Euro-centric. As readers, we can only see what Marlow, or the interest group that he represent, wants us to see. While the black indigenous people, those who were actually being exploited, considering the fact that they were given no voice to, could only watch in despair whatever Marlow the white pleased to call them, usually in a manner that could best benefit those on his side, of course. In this regard, in choosing Marlow as the sole information provider and commentator, Conrad also rendered himself in an unconvincing situation when his alleged anti-colonialism stance is concerned. One cannot help but question: shouldn’t this kind of division pro-colonialist?

\subsection{The Presence of A Contrived Dualistic Distinction Between "Us" and "Other"}

According to Jacques Lacan's famous mirror stage theory, the identification of "us" is often carried out through references to the "other" and that it is through the establishment of such relationship with the "other" that the identification of "us" is achieved (53). Interests in "other" are only motivated by concerns for "us". More often than not, it is through the opposite or negative "other" that the authority of "us" is defined(Boehmer 21). This process of othering is fundamental in colonization in that it is by representing the colonized people, the "other", as lesser -- less human, less civilized, as child or savage, wild man, animal, or perhaps headless mass, that the expansion enterprise of the allegedly superior Europeans, the "us", gets justified.

This is exactly the case in Conrad's novel Heart of Darkness. Prejudice against and belittling of the Congo region and its indigenous people prevails in the whole work.

In sharp contrast to the grand glittering Thames Estuary, the whole Cogon River, along with regions along its banks were described as dark, uncivilized and corrupting (Conrad 10). As for its people, who never appeared as complete figures on the scene, were always depicted as foolish barbarous good-for-nothings. They had no individuality, but were an uncivilized mass, who would get freaked out on the mere hearing of the harmless sound of whistles when they were not afraid of those deadly weapons like guns, and would be foolish enough to believe in the existence of a demon in the boiler. In a word, the ignorance of them was depicted as such that Marlow can not help but feel thrilled at the thought of his kinship with those of wild and passionate uproar (Conrad 51) and their identify as human. Maybe pre-historical cannibals would be a more favorable term in the narrator's mind. Anyway, though Marlow himself has stated that he had never seen them eat each other before his face (Conrad 51), he insisted in taking them as cannibals and when his black helmsman died, he threw the body into river immediately, secretly rejoicing at his success in avoiding a potential clash among those "cannibals" who might scramble for the flesh (Conrad 72).

While on the other hand, irresponsible and malicious as those white Europeans may seem, the very means they adopted in passing the buck or trapping each other precisely demonstrated their intellectual superiority. In this regard, the gap between the European "us" and African "other” is so 
obvious that the manager(a white man) concluded that physical advantage alone could make a hard core in colonial rule(Conrad 72), even at the absence of morality or ability.

As is clear in the foregoing description, Europeans, as represented by Marlow, got ceaselessly reconfirmed in their identity and superiority by finding for itself a subterranean or reverse self, a dark mirror image (Conrad 72) in those barbarous indigenous Africans. Indeed, images of the natives should be tarnished so as to justify and ennoble their undertaking there. So, in spite of all those intended information Conrad declared to relay, one can always hear another sound, a background one conveying implicit messages Conrad himself may not have noticed. Yet from this sound, its assumption of a contrived distinction between the white "us" and the black "other", one can clearly sense the unconscious colonial tendency in the author.

\subsection{Tacit Approval of Europe's Culture Hegemony}

According to Italian Marxist Antonia Gramsci, hegemony is the ruling class's domination through ideology and the shaping of popular consent. To say it more specifically, it is the domination of a culturally diverse society by the ruling class, who manipulate the culture of the society---the beliefs, explanations, perceptions, values, and mores---so that their ruling-class Weltanschauung becomes the worldview which is imposed and accepted as the universally valid dominant ideology, the cultural norm. Apart from industrial and military power, this explicit ideologies of moral, cultural, and racial supremacy which backed its interpretive venture is just what distinguishes the colonial mission of nineteenth-century Europe. In achieving doing so, the colonizing nations in Europe managed to weave an interpretive net over much of the earth's surface and validating their imperial rule as well.

Naturally, with its unparallel reach and authority, literary works turned out to be an excellent way in promoting such hegemony for western powers, usually in a subtle and implicit way, thus hard to detect and guard against. This is why Conrad, who is usually considered to be anti-colonialism, is also suspected of being involved in such propaganda when his works is scrutinized in terms of ideologies it espouses.

Indeed, anyone who cares to read the novel under discussion in detail would find plenty of such western ideologies forcing its way into the colonized region. The most obvious one is the western value system. For the westerners, work and efficiency are paramount, so things like sense of time and labor contract are greatly valued. When in contact with natives in the Congo River region, western settlers brough these thing with them and applied it there. Even when they knew that the natives had no clear idea of time, nor did they understand what those paper they were asked to sign meant. So those natives would never know exactly when their contracted working time, say three month, was due and therefore were constantly in the unfavorable condition of being exploited through working overtime. Another problem those natives had to face was that concerning payment. It was true that they were paid fairly high according to what those settler said. Yet the payment, in the form of brass wire, meant nothing to those starving crews who could neither eat the brass wire, nor did they had the chace to exchange it for food (Conrad 58). Above all, the most undisguised imposing of western ideology on the natives was manifested in Marlow's final comment on his late helmsman as a helpful instrument Conrad 71). "He was useful, because he has been trained.” This was Marlow's logic in giving his final judgment. No trace of consideration, let alone respect, for the natives' value system could be found. Anyway, in this foreign land, they were the boss.

Those listed above are only a tip of the iceberg. As a matter of fact, cultural hegemony like this, by means of imposed ideologies, prevailed in every air of Marlow's narration, in the novel and, judging from his natural depiction, in Conrad's subconscious as well. Like Marlow, though alleged to be despised of the aggression of those settlers yet actually joined them when he showed utmost respect to Kurtz(the most active colonists among all), Conrad himself also fell back into their side when he failed in detecting his pro-colonial tendency and gave rein to those spontaneous expressions.

\section{Conclusion}

As is acknowledged by all, those expressed spontaneously is exactly what exists in ones subconscious, which to some degrees represents some of one's nature, if not the whole real self. So 
while analyzing Heart of Darkness, Conrad's open criticism of those western setters acknowledged, his spontaneous overflow of colonialist consciousness, covertly expressed in his one-sided division of discourse power, the assumption of a contrived dualistic distinction between "us" and "other", and his tacit approval of Europe's culture hegemony, should by no means be ignored. Just like, due to his special life experience, the co-existence of "us" and "other" in himself, both anti-colonialism (as widely acknowledge by others) and pro-colonialism tendency co-existed in him as well.

So through this analysis, the intended message is that whatever one is faced up with, the advisable thing to do is the retaining of a critical mind, exactly as what we should do in our critical reading of Conrad's novel Heart of Darkness. Anyway, only in keeping a watchful eye for both sides, explicit and implicit, will one not be manipulated and see the world for his own.

\section{References}

[1]. Elleke Boehmer, Colonial and Postcolonial Literature, Oxford University Press, 2005.

[2]. Edward W. Said, Orientalism, Knopf Group, 1979.

[3]. Geoffrey Galt Harpman. One of Us, The Mastery of Joseph Conrad. The University of Chicago Press, 1996.

[4]. Joseph Conrad, Heart of Darkness, Shanghai Foreign Language Univresity Press, 2004.

[5]. Michel Foucault, “The Order of Discourse”, Untying the Text: A Post-structuralist Reader, Edited by Robert Young (48 78). Routledge \& Kegan Paul, 1998. 